\title{
RESEARCH ON MAXIMIZING CRITICAL AND REDUCING INITIAL HEAT FLUX DENSITIES TO ELIMINATE ANY FILM BOILING AND MINIMIZE DISTORTION DURING QUENCHING
}

\author{
Nikolai Kobasko \\ Intensive Technologies Ltd \\ 68/1 Peremohy ave., Kyiv, Ukraine, 03113 \\ nkobasko@gmail.com \\ Anatolii Moskalenko \\ Thermo-Acoustical Diagnostic of Heat Transfer Processes \\ Institute of Engineering Thermophysics of NASU \\ 2A Zhelyabova str., Kyiv, Ukraine, 03057 \\ an.moskalenko@gmail.com \\ Petro Lohvynenko \\ Department of Polymers Modification \\ Institute of Macromolecular Chemistry of NASU \\ 48 Kharkivske road, Kyiv, Ukraine, 02160 \\ petmol@ukr.net \\ Volodymyr Dobryvechir \\ Intensive Technologies Ltd \\ 68/1 Peremohy ave., Kyiv, Ukraine, 03113 \\ dobrivecher@yahoo.com
}

\begin{abstract}
In the paper the results of testing three types of FUCHS oils: Thermisol QH 120, Thermisol QH 10 and Thermisol QB 46 are discussed. The main attention is paid to critical heat flux densities evaluation because they create a basis for optimizing cooling intensity of any liquid quenchant. In the paper is underlined that any film boiling during quenching is undesirable since it is a reason for big distortion and non-uniform surface harness. It is shown that intensive quenching decreases distortion of steel parts during quenching. To eliminate film boiling during quenching in mineral oils, optimal temperature of oil should be chosen which maximize the first critical heat flux density and special additives should be used to decrease initial heat flux by creating surface micro-coating. Along with the evaluation of heat transfer coefficients, critical heat flux densities inherent to liquid quenchant must be measured first to optimize quenching processes. International DATABASE on cooling characteristics of liquid quenchants must include critical heat flux densities, initial heat flux densities, and heat transfer coefficients allowing optimizing and governing quenching processes.

Keywords: critical heat flux, initial heat flux, optimization, database, distortion, calculations, cooling intensity, mineral oils.

\section{Introduction}

In the paper a main attention is paid to critical and initial heat flux densities which should be included in DATABASE which is currently developing by international team in the frame of International Federation for Heat Treatment and Surface Engineering (IFHTSE). It is shown that critical heat flux densities are the main parameters in the first step of evaluating cooling capacity the different kinds of quenchants. Depending on a ratio between initial and the first critical heat flux, it could be four possible heat-transfer modes on their hot metal surface $[1,2]$. At the first type of heat-transfer mode full film boiling and nucleate boiling are present simultaneously on the probe surface. The rewetting front accompanying the transition from full film boiling, which occurs during the cooling process, typically moves axially along the metal surface during cooling. At the
\end{abstract}


second type of heat-transfer mode initially, film boiling occurs over the entire hot metal surface. At a certain point in time, nucleate boiling instantaneously replaces film boiling. When boiling ceases, convection heat transfer occurs [1,2]. At the third type of heat-transfer mode some localized areas of the probe surface are covered by a vapor blanket, whereas at the same time other areas experience nucleate boiling. At fourth type of heat-transfer mode the film boiling and nucleate boiling periodically replace each other during quenching $[1,2]$. For each type of nucleate boiling process its own specific boundary condition are used to solve correctly direct and inverse heat conductivity problems. It means that it is impossible to solve mentioned above direct and inverse problem without knowing the type of heat transfer mode. Authors of current work in their investigations used additional tools like noise control system and high speed video recording to be sure that type of film boiling was chosen correctly. In the paper the second type of heat transfer mode is considered since it was observed during testing of Inconel 600 probe in three types of oils: Thermisol QH 120, Thermisol QH 10 and Thermisol QB 46 delivered by IFHTSE for Robin Round testing with the aim of designing Liquid Quenchant Database. These oils differ from each other by their viscosity and are widely use in practice. Taking into account that for each mineral oil exists optimal bath temperature where the first critical heat flux density has maximum value (Fig. 1). It was decided to make testing for three types of oils within the wide diapason of temperatures: $30{ }^{\circ} \mathrm{C}, 50{ }^{\circ} \mathrm{C}, 70{ }^{\circ} \mathrm{C}$, $90{ }^{\circ} \mathrm{C}$ and $110^{\circ} \mathrm{C}$.

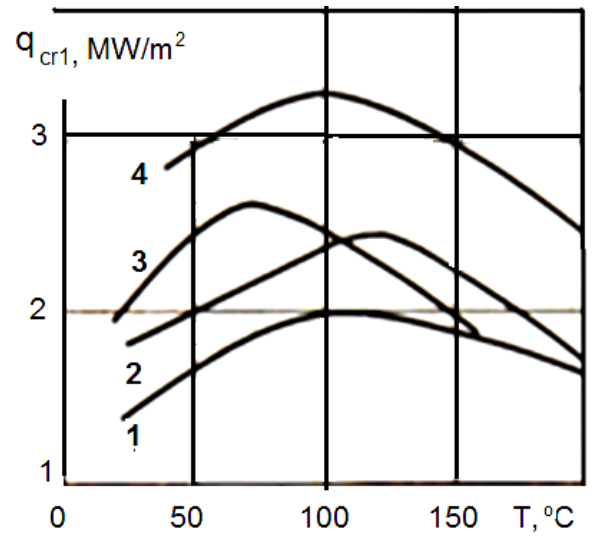

Fig. 1. The first critical heat flux density $\mathrm{q}_{\mathrm{crl}}$ versus temperature of mineral oils: 1 - MZM-120; 2 - MS; 3 - Effectol; 4 - MZM-16 [3]

As seen from Fig. 1, there is an optimal temperature for mineral oils where the first critical heat flux density reaches maximum value. That is why, it is important for practical use investigate three types of FUCHS oils at elevated temperatures.

\section{Simplified procedure for evaluating critical heat flux densities}

For evaluating critical heat flux densities, developed film boiling during quenching should take place. For this purpose standard probe made of high thermal conductivity material, for example silver, should be used. Standard Inconel 600 probe also can provide information on critical heat flux densities if film boiling during quenching is clearly seen [4, 5]. Measuring transition temperature from film boiling to nucleate boiling and evaluating heat transfer coefficient at this temperature, it is possible to calculate the second critical heat flux density $\mathrm{q}_{\mathrm{cr} 2}$. The first critical heat flux density is evaluated then from the well known correlation $\mathrm{q}_{\mathrm{cr} 2} / \mathrm{q}_{\mathrm{crl}}=0.2[6-8]$. Heat transfer coefficients (HTC) are evaluated by solving inverse problem [9]. For evaluating HTC, author of the paper used regular thermal condition theory [10] which provides good results of calculation for any Biot number Bi with the accuracy about $\pm 3 \%$. Below, the main equation of regular thermal condition theory are considered and examples of calculating critical heat flux density is provided. To make such calculations, cooling curves and cooling rates should be available (Fig. 2, 3). 


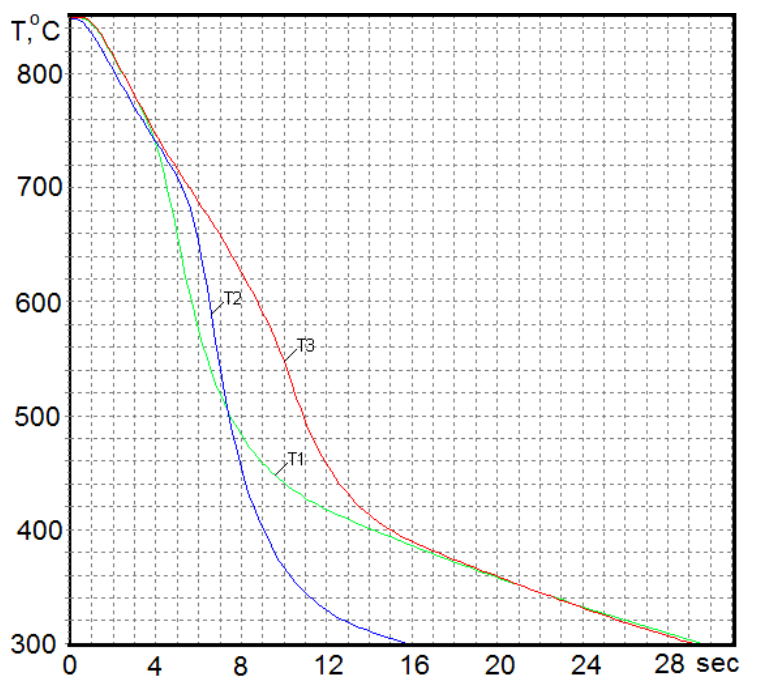

Fig. 2. Cooling curves for different types of oils at $50{ }^{\circ} \mathrm{C}$ : 1 - Thermisol QH 120; 2 - Thermisol QH 10; 3 - Thermisol QB 46

Cooling rate,, $\mathrm{C} / \mathrm{s}$

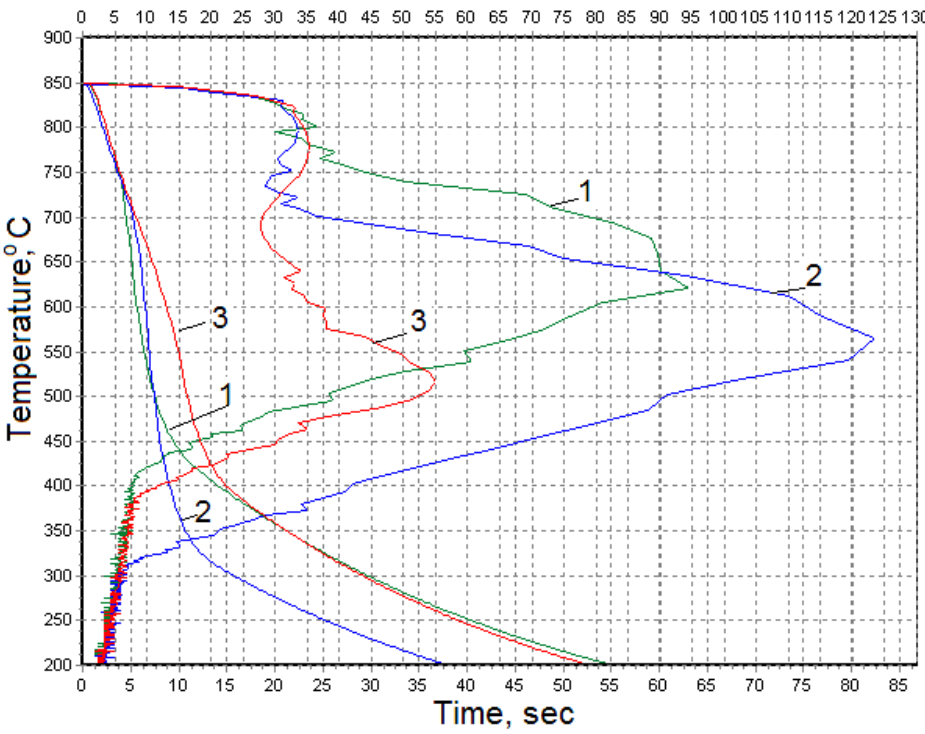

Fig. 3. Cooling rate for different types of oils at $50^{\circ} \mathrm{C}$ :

1 - Thermisol QH 120; 2 - Thermisol QH 10; 3 - Thermisol QB 46

Kondratjev number Kn, according to regular thermal condition, is evaluated as $[6,10]$ :

$$
\mathrm{Kn}=\frac{\mathrm{vK}}{\mathrm{a}\left(\mathrm{T}-\mathrm{T}_{\mathrm{m}}\right)} .
$$

Generalized Biot number is evaluated from universal correlation

$$
\mathrm{Kn}=\psi \mathrm{Bi}_{\mathrm{V}} \text { or } \mathrm{Kn}=\frac{\mathrm{Bi}_{\mathrm{V}}}{\sqrt{\mathrm{Bi}_{\mathrm{V}}{ }^{2}+1.437 \mathrm{Bi}_{\mathrm{V}}}+1}
$$

and then heat transfer coefficient is evaluated as: 


$$
\alpha=\frac{\lambda \mathrm{Bi}_{\mathrm{V}} \mathrm{R}}{2 \mathrm{~K}} .
$$

The second critical heat flux density is calculated from the equation

$$
\mathrm{q}_{\mathrm{cr} 2}=\alpha_{\mathrm{F}}\left(\mathrm{T}_{\mathrm{tr}}-\mathrm{T}_{\mathrm{m}}\right)
$$

Taking into account that $\mathrm{q}_{\mathrm{cr} 2} / \mathrm{q}_{\mathrm{cr} 1}=0.2$, it easy to calculate approximately the first critical heat flux density using Eq. (5) [11]:

$$
\mathrm{q}_{\mathrm{cr} 1}=5 \alpha_{\mathrm{F}}\left(\mathrm{T}_{\mathrm{tr}}-\mathrm{T}_{\mathrm{m}}\right)
$$

Let's calculate critical heat flux densities from data provided in Fig. 2. Minimum cooling rate for oil Thermisol QH 10 is $29^{\circ} \mathrm{C} / \mathrm{s}$ at core temperature $740{ }^{\circ} \mathrm{C}$. Thermal conductivity and thermal diffusivity at this temperature are: $26 \mathrm{~W} / \mathrm{mK}$ and $5.65 \times 10^{-6} \mathrm{~m}^{2} / \mathrm{s}$. According to (1), $\mathrm{Kn}$ is calculated as

$$
\mathrm{Kn}=\frac{29^{\circ} \mathrm{C} / \mathrm{s} \times 6.75 \times 10^{-6} \mathrm{~m}^{2}}{5.65 \times 10^{-6} \mathrm{~m}^{2} / \mathrm{s}\left(740^{\circ} \mathrm{C}-50{ }^{\circ} \mathrm{C}\right)}=0.05
$$

Generalized Biot number according to Eq. (2) is 0.055. It means that

$$
\begin{gathered}
\alpha_{\mathrm{F}}=\frac{29 \mathrm{~W} / \mathrm{mK} \times 0.055 \times 0.00625 \mathrm{~m}}{2 \times 6.75 \times 10^{-6} \mathrm{~m}^{2}}=738 \mathrm{~W} / \mathrm{m}^{2} \mathrm{~K} ; \\
\mathrm{q}_{\mathrm{cr} 2}=738 \mathrm{~W} / \mathrm{m}^{2} \mathrm{~K} \times\left(740{ }^{\circ} \mathrm{C}-50{ }^{\circ} \mathrm{C}\right)=509220 \mathrm{~W} / \mathrm{m}^{2} ; \\
\mathrm{q}_{\mathrm{cr} 1}=5 \times 738 \mathrm{~W} / \mathrm{m}^{2} \mathrm{~K} \times\left(740{ }^{\circ} \mathrm{C}-50{ }^{\circ} \mathrm{C}\right)=2.55 \mathrm{MW} / \mathrm{m}^{2} .
\end{gathered}
$$

As seen from Fig. 1, the first critical heat flux density for Thermisol QH 10 is equal to Effectol oil (curve 3).

\section{Effect of oil temperature on its cooling characteristics}

Temperature of Thermisol oil QH 120 affects considerably its cooling characteristics as shown in Fig. 4. Along with increasing critical heat flux densities, temperature increases heat transfer coefficients providing more uniform and more accelerated cooling of steel parts. To proof this statement, below maximal HTCs are calculated using (1)-(5):

At temperature $30{ }^{\circ} \mathrm{C}$

$$
\mathrm{Kn}=\frac{76{ }^{\circ} \mathrm{C} / \mathrm{s} \times 6.75 \times 10^{-6} \mathrm{~m}^{2}}{5.4 \mathrm{~m}^{2} / \mathrm{s}\left(612{ }^{\circ} \mathrm{C}-30{ }^{\circ} \mathrm{C}\right)}=0.16 \text { and } \mathrm{Bi}_{\mathrm{v}}=0.18
$$

HTC in this case is equal to

$$
\alpha=\frac{23.7 \mathrm{~W} / \mathrm{mK} \times 0.18 \times 0.00625 \mathrm{~m}}{2 \times 6.75 \times 10^{-6} \mathrm{~m}^{2}}=1975 \mathrm{~W} / \mathrm{m}^{2} \mathrm{~K}
$$

At temperature $110{ }^{\circ} \mathrm{C}$

$$
\mathrm{Kn}=\frac{112.5^{\circ} \mathrm{C} / \mathrm{s} \times 6.75 \times 10^{-6} \mathrm{~m}^{2}}{5.45 \mathrm{~m}^{2} / \mathrm{s}\left(648{ }^{\circ} \mathrm{C}-110^{\circ} \mathrm{C}\right)}=0.26 \text { and } \mathrm{Bi}_{\mathrm{V}}=0.325 .
$$


In this case HTC is equal to

$$
\alpha=\frac{24.8 \mathrm{~W} / \mathrm{mK} \times 0.325 \times 0.00625 \mathrm{~m}}{2 \times 6.75 \times 10^{-6} \mathrm{~m}^{2}}=3730 \mathrm{~W} / \mathrm{m}^{2} \mathrm{~K}
$$

Increasing is 1.88 times.

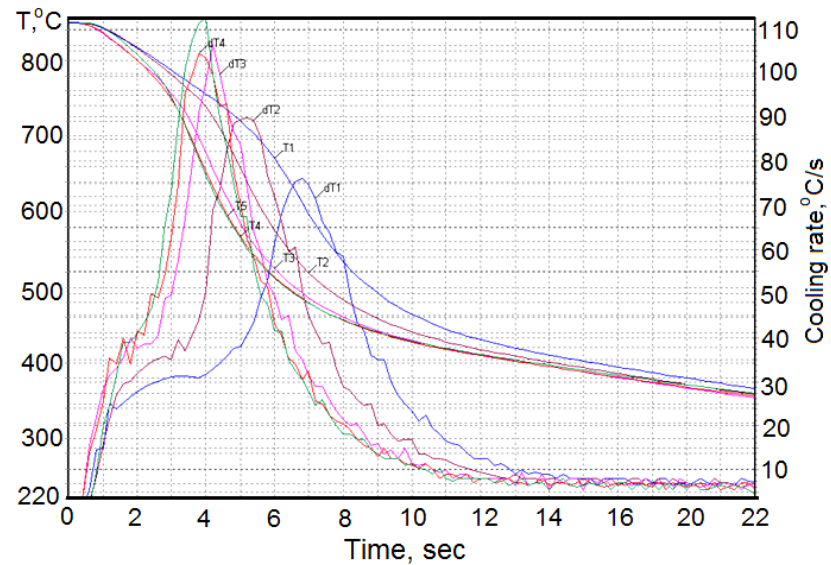

Fig. 4. Cooling curves and cooling rates depending on temperature of Thermisol QH 120 oil: $1-30{ }^{\circ} \mathrm{C} ; 2-50{ }^{\circ} \mathrm{C} ; 3-70{ }^{\circ} \mathrm{C} ; 4-90{ }^{\circ} \mathrm{C} ; 5-110^{\circ} \mathrm{C}$

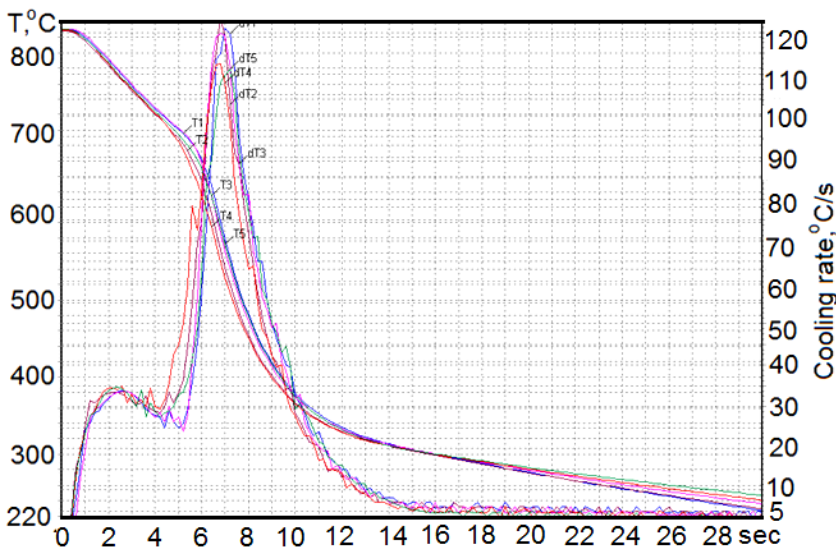

Fig. 5. Cooling curves and cooling rates depending on temperature of Thermisol QH 10 oil:

$$
1-30{ }^{\circ} \mathrm{C} ; 2-50{ }^{\circ} \mathrm{C} ; 3-70{ }^{\circ} \mathrm{C} ; 4-90{ }^{\circ} \mathrm{C} ; 5-110{ }^{\circ} \mathrm{C}
$$

The Thermisol QH 120 is high quality oil with a low level of evaporation and can work at elevated temperature as a quenchant reducing significantly distortion. In contrast to Thermisol QH 120 oil, Thermisol QH 10 oil doesn't react significantly on its temperature changing (Fig. 5). With increase temperature critical heat flux densities and HTCs increase insignificantly. For example, at temperature $30{ }^{\circ} \mathrm{C}$

$$
\mathrm{Kn}=\frac{121{ }^{\circ} \mathrm{C} / \mathrm{s} \times 6.75 \times 10^{-6} \mathrm{~m}^{2}}{5.35 \mathrm{~m}^{2} / \mathrm{s}\left(579{ }^{\circ} \mathrm{C}-30^{\circ} \mathrm{C}\right)}=0.278 \text { and } \mathrm{Bi}_{\mathrm{V}}=0.36
$$

HTC in this case is equal to

$$
\alpha=\frac{237 \mathrm{~W} / \mathrm{mK} \times 0.36 \times 0.00625 \mathrm{~m}}{2 \times 6.75 \times 10^{-6} \mathrm{~m}^{2}}=3830 \mathrm{~W} / \mathrm{m}^{2} \mathrm{~K}
$$


At temperature $110^{\circ} \mathrm{C}$

$$
\mathrm{Kn}=\frac{111.2^{\circ} \mathrm{C} / \mathrm{s} \times 6.75 \times 10^{-6} \mathrm{~m}^{2}}{5.2 \mathrm{~m}^{2} / \mathrm{s}\left(549{ }^{\circ} \mathrm{C}-110^{\circ} \mathrm{C}\right)}=0.329 \text { and } \mathrm{Bi}_{\mathrm{V}}=0.442
$$

In this case $\mathrm{HTC}$ is equal to

$$
\alpha=\frac{22.7 \mathrm{~W} / \mathrm{mK} \times 0.442 \times 0.00625 \mathrm{~m}}{2 \times 6.75 \times 10^{-6} \mathrm{~m}^{2}}=4645 \mathrm{~W} / \mathrm{m}^{2} \mathrm{~K}
$$

Increasing is 1.2 times.

Experiments and calculations show that Thermal QH 10 oil is stable and insignificantly changes with changing its temperature. Manufacturer FUCHS is recommended this oil for forgings directly from the forge heat, quenching of wrought materials, screws and springs [12].

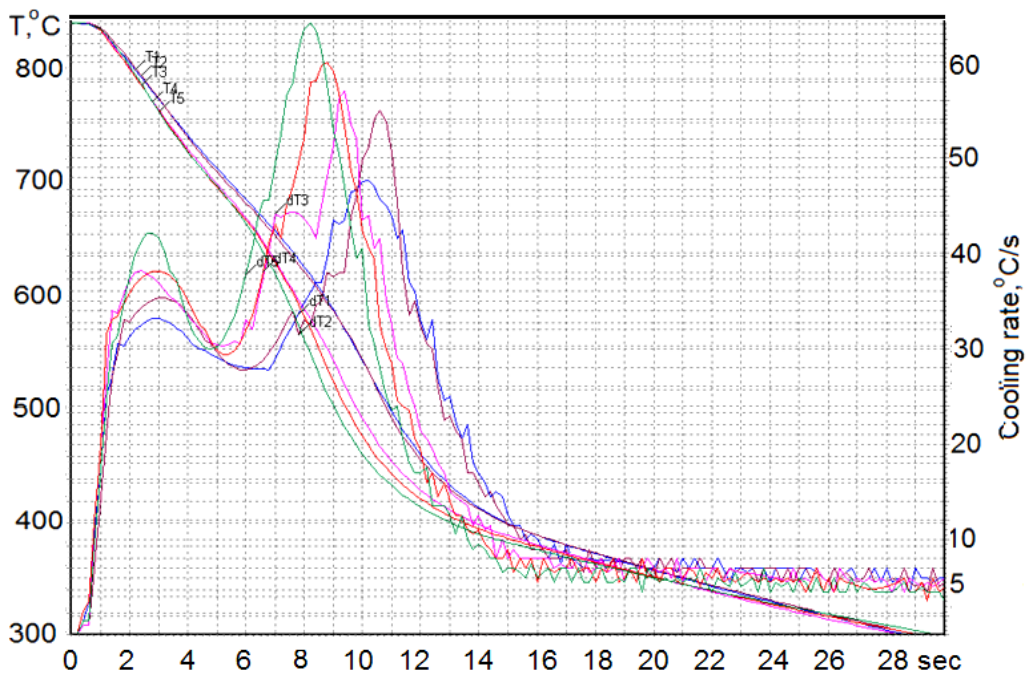

Fig. 6. Cooling curves and cooling rates depending on temperature of Thermisol QB 46 oil:

$$
1-30{ }^{\circ} \mathrm{C} ; 2-50{ }^{\circ} \mathrm{C} ; 3-70{ }^{\circ} \mathrm{C} ; 4-90{ }^{\circ} \mathrm{C} ; 5-110^{\circ} \mathrm{C}
$$

At temperature $30^{\circ} \mathrm{C}$

$$
\mathrm{Kn}=\frac{47.6{ }^{\circ} \mathrm{C} / \mathrm{s} \times 6.75 \times 10^{-6} \mathrm{~m}^{2}}{5.17 \mathrm{~m}^{2} / \mathrm{s}\left(537^{\circ} \mathrm{C}-30{ }^{\circ} \mathrm{C}\right)}=0.123 \text { and } \mathrm{Bi}_{\mathrm{V}}=0.14
$$

HTC in this case is equal to

$$
\alpha=\frac{22.5 \mathrm{~W} / \mathrm{mK} \times 0.14 \times 0.00625 \mathrm{~m}}{2 \times 6.75 \times 10^{-6} \mathrm{~m}^{2}}=1460 \mathrm{~W} / \mathrm{m}^{2} \mathrm{~K} .
$$

At temperature $110{ }^{\circ} \mathrm{C}$

$$
\mathrm{Kn}=\frac{64.1{ }^{\circ} \mathrm{C} / \mathrm{s} \times 6.75 \times 10^{-6} \mathrm{~m}^{2}}{5.2 \mathrm{~m}^{2} / \mathrm{s}\left(553{ }^{\circ} \mathrm{C}-110^{\circ} \mathrm{C}\right)}=0.188 \text { and } \mathrm{Bi}_{\mathrm{V}}=0.22
$$


In this case HTC is equal to

$$
\alpha=\frac{22.7 \mathrm{~W} / \mathrm{mK} \times 0.22 \times 0.00625 \mathrm{~m}}{2 \times 6.75 \times 10^{-6} \mathrm{~m}^{2}}=2310 \mathrm{~W} / \mathrm{m}^{2} \mathrm{~K} .
$$

Increasing is 1.58 times.

Thermisol QB 46 oil (Fig. 6) provides uniform cooling and is thermal stable. It displays good resistance to ageing and do not evaporate excessively [12].

Thus, increasing temperature of oil increases the first critical heat flux density and HTC that in many cases eliminates undesirable film boiling. Also, special additives creating micro-insulating layer on the surface of steel parts are used to decrease initial heat flux density and by this way eliminate film boiling (Fig. 7) [13, 14].

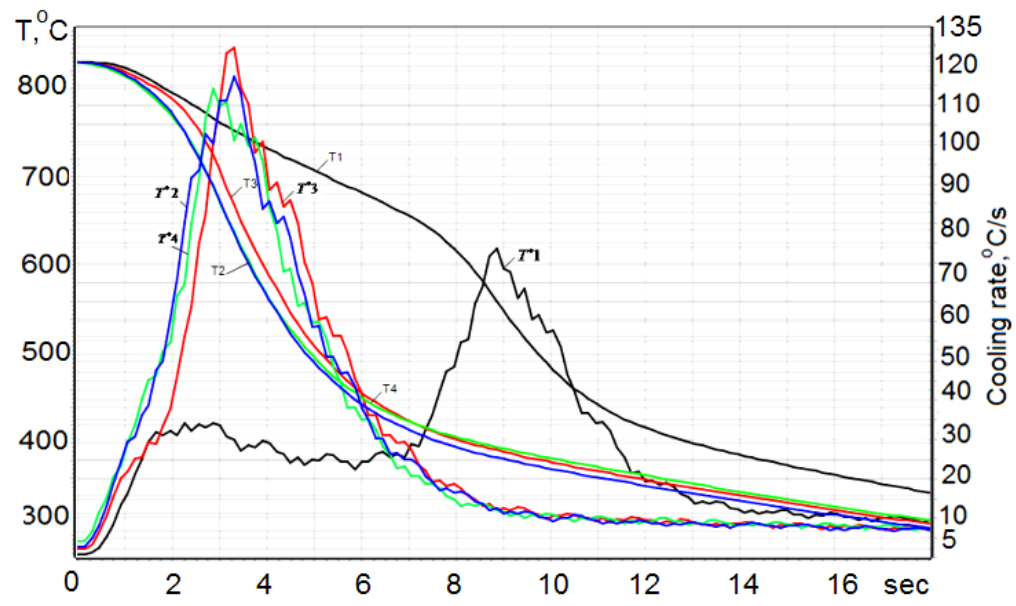

Fig. 7. Temperature $\mathrm{T}$ and cooling rate $\mathrm{T}^{*}$ at the center of Inconel 600 probe $10 \mathrm{~mm}$ in diameter and $30 \mathrm{~mm}$ long versus time when quenching in oil I-20 A at $50{ }^{\circ} \mathrm{C}: 1-$ no additives at all; 2-7 \% of PIB 950; 3-5\% of PIB 1300; 4-4 \% of PIB $2400[13,14]$

As seen from Fig. 7, a small amount of PIB additives decrease completely film boiling during quenching due to creation of an insulating layer $[13,14]$. This is a new approach in controlling cooling intensity of liquid quenchants.

\section{Discussion}

In last decade, numerous experiments were fulfilled to show that intensive and uniform quenching doesn't decrease distortion. In contrary, it decreases distortion (Fig. 8) [6].

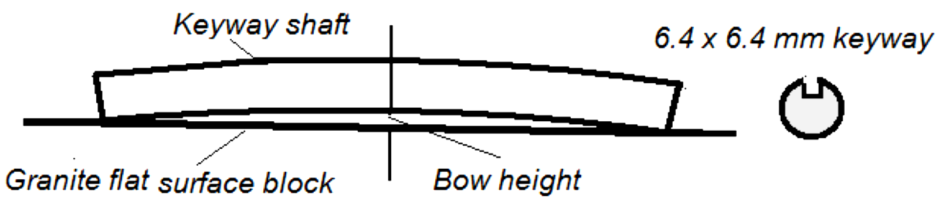

Fig. 8. Keyway shaft distortions [6]

Many others experiments were made connected with the measuring distortion of cylindrical steel parts after quenching in water flow up to $12 \mathrm{~m} / \mathrm{s}$ where distortion was minimal (Fig. 8, Table 5). It means that film boiling can be eliminated completely without resulting in increasing distortion.

Thus, critical heat flux densities are very important values responsible for eliminating film boiling processes and they should be in DATABASE as a characteristic of any liquid quenchant. 
Also, special additives to liquid quenchant should be investigated which create insulating layers on the surface of steel parts and contemporary methods for their testing should be developed. Some information concerning this issue is provided in [16-21].

Table 5

Keyway distortion measurements [6]

\begin{tabular}{ccc}
\hline Batch oil & Single oil & Single IQ \\
\hline $0.25-0.51 \mathrm{~mm}$ & $0.20-0.36 \mathrm{~mm}$ & $0.08-0.12 \mathrm{~mm}$
\end{tabular}

\section{Conclusions}

1. Liquid quenchant database should contain critical heat flux densities as the main parameters for any liquid used as a quenchant.

2. There is an optimal temperature of liquid where critical heat flux densities are maximal and distortion after quenching steel parts in optimal condition is minimal.

3. Any film boiling, especially local film boiling, during quenching is undesirable since it is a reason for big distortion and non-uniform surface hardness.

4. To eliminate any film boiling during quenching, one should increase critical heat flux densities and decrease initial heat flux during immersion of steel parts into cold liquid.

5. Up to present time, the main attention was paid to changing surface tension in order to control cooling intensity of liquid quenchants. Authors proposed to use insulating layers to decrease initial heat flux density and by this way eliminate film boiling.

6. New additives to liquid quenchants, which create insulating layers, should be further investigated and widely introduced to practice.

\section{Acknowledgement}

Authors are very grateful to FUCHS and IFHTSE for providing and delivering Thermisol GH 120, Thermisol GH 10 and Thermisol GB 46 oils for laboratory investigations in the frame of liquid quenchant DATABASE development.

\section{References}

[1] Mayinger, F. (1992). Thermo- and Fluiddynamic Principles of Heat Transfer During Cooling. Theory and Technology of Quenching, 41-72. doi: 10.1007/978-3-662-01596-4_3

[2] Liscic, B. (2016). Measurement and Recording of Quenching Intensity in Workshop Conditions Based on Temperature Gradients. Materials Performance and Characterization, 5 (1), MPC20160007. doi: 10.1520/mpc20160007

[3] Kobasko, N. I. (1980). Steel Quenching in Liquid Media Under Pressure. Kyiv: Naukova Dumka, 206.

[4] ISO 9950. Industrial Quenching Oils-Determination of Cooling Characteristics- Nickel-Alloy Probe Test Method, 1995(E) (1995). International Organization for Standardization, Geneva, Switzerland.

[5] ASTM D6200-01. Standard Test Method for Determination of Cooling Characteristics of Quench Oils by Cooling Curve Analysis (2012). ASTM International, West Conshohocken, PA. Available at: https://www.astm.org/cis/ru/index.html

[6] Kobasko, N. I., Aronov, M. A., Powell, J. A., Totten, G. E. (2010). Intensive Quenching Systems: Engineering and Design. ASTM International, West Conshohocken, USA, 234. doi: 10.1520/mnl64-eb

[7] Kobasko, N. I., Batista, A. A., Canale, L. C. F., Totten, G. E., Dobryvechir, V. V. (2013). Cooling Capacity of Coconut Oil, Palm Oil, and a Commercial Petroleum Oil by Solving the Heat Conductivity Inverse Problem. Materials Performance and Characterization, 2 (1), 20120047. doi: 10.1520/mpc20120047

[8] Kobasko, N. I., Marques, A., Canale, L. C. F., Totten, G. E., Dobryvechir, V. V. (2013). Cooling Capacity of Petroleum Oil Quenchants as a Function of Bath Temperature. Materials Performance and Characterization, 2 (1), 20130004. doi: 10.1520/mpc20130004 
[9] Felde, I. (2015). Liquid Quenchant Database - Determination of Heat Transfer Coefficient during Quenching. IDE 2015, Bremen, Germany, 265-274.

[10] Kondratiev, G. M. (1957). Teplovye izmereniya [Thermal Measurements]. Moscow: Mashgiz, 244.

[11] Kobasko, N. I. (2011). Why Database for Cooling Capacity of Various Quenchants Should be Developed? Vol. V. COMPUTERS and SIMULATION in MODERN SCIENCE, 142-147. uct $\_$id $=317$

[12] FUCHS. Available at: http://mactexoil.ie/index.php?route=product/product\&path=86\&prod-

[13] Lohvynenko, P. N., Moskalenko, A. A., Kobasko, N. I., Karsim, L. O., Riabov, S. V. (2016). Experimental Investigation of the Effect of Polyisobutilene Additives to Mineral Oil on Cooling Characteristics. Materials Performance and Characterization, 5 (1), MPC20150072. doi: 10.1520/mpc20150072

[14] Kobasko, N., Moskalenko, A., Lohvynenko, P., Karsim, L., Riabov, S. (2016). An effect of pib additives to mineral oil resulting in elimination of film boiling during steel parts quenching. EUREKA: Physics and Engineering, 3, 17-24. doi: 10.21303/2461-4262.2016.00076

[15] Liscic, B., Filetin, T. (2011). Global Database of Cooling Intensities of Liquid Quenchants. Proceedings of the European Conference on Heat Treatment. Quality in Heat Treatment, 40-49.

[16] Tensi, H. M., Totten, G. E., Kunzel, T. (2000). Physics and Technology of Quenching in Fluids Part I. The 12th IFHTSE Congress Proceedings, 1-4.

[17] Totten, G. E., Bates, C. E., Clinton, M. A. (1993). Handbook of Quenchants and Quenching Technology. Materials Park, Ohio: ASM International, 507.

[18] UCONTM Fluids and Lubricants - Quenchants. The Dow Chemical Company. Available at: http://www.dow.com/ucon/formulated/fluids/quench.htm

[19] The Dow Chemical Company (2015). UCONTM ULTRAQUENCH ${ }^{\mathrm{TM}}$. A Plus Quenchant. Available at: http://chemtool.com/wp-content/uploads/2015/07/UCON-Ultraquench-A-Plus.pdf

[20] ASTM Standard D6482-99. Standard Test Method for Determination of Cooling Characteristics of Aqueous Polymer Quenchants with Agitation (Tensi Method) (2000). Annual Book of ASTM Standards. West Conshohocken, PA: ASTM International. doi: 10.1520/d6482-99

[21] ASTM Standard D6549-00. Standard Test Method for Determination of Cooling Characteristics of Quenchants by Cooling Curve Analysis with Agitation (Drayton Unit) (2000). Annual Book of ASTM Standards. West Conshohocken, PA: ASTM International. doi: 10.1520/d6549-00 